\title{
Применение генетических и биоинформационных подходов к познанию биоразнообразия на примере эндемичных рыбьих пиявок Baicalobdella (Hirudinea, Piscicolidae) из озера Байкал
}

\author{
Матвеенко Е.Ю. *, Кайгородова И.А. \\ Лимнологический институт СО РАН, Иркутск, Россия \\ *e-mail:matveenko@lin.irk.ru
}

Ключевые слова: филогенетическое разнообразие, криптические виды, Baicalobdella, Байкал

Мотивация и цель: Экологические исследования требуют точного и быстрого определения уровней биоразнообразия без использования традиционного морфологического анализа. Для решения этой задачи разработан целый ряд методов молекулярной экологии. В данной работе был апробирован набор биоинформационных методов, обеспечивающих объективную оценку различий между внутривидовой и межвидовой вариабельностью. В качестве модельного объекта использован набор нуклеотидных последовательностей фрагмента coxl двух популяций пиявок рода Baicalobdella (Dogiel, 1957), паразитирующих на эндемичных амфиподах Байкала, и трудно идентифицируемых морфологически.

Материалы и методы исследования: Биологический материал отобран по всей акватории оз. Байкал и в верхнем течении р. Ангара в диапазоне глубин 0-285 м. Морфологическое определение видовой принадлежности проведено в соответствии с исходным и более поздним дополненным описанием вида. Для молекулярного анализа использовали фрагмент гена, кодирующего coxl, широко применяемый в ДНК-штрихкодировании. Биоинформационный анализ генетических данных проводился на основе нескольких альтернативных методов, включая байесовский метод, реализованный в BEAST v. 1.8.4, алгоритм GMYC, программа ABGD и пакет программ MEGA 7. Результаты и обсуждение: Согласно современной классификации 65 образцов были отнесены к виду B. torquata. Однако в этой группе уровень генетического полиморфизма (р) составляет $0,049 \pm$ 0,006, что вдвое превышает пороговое значение. Согласно теории ДНК-штрихкодирования coxl анализ выявил две четко выраженные клады в пределах филогенетической линии B. torquata. Подразделение вида соотносится с географической приуроченностью образцов к северной и южной котловинам озера. Высокий показатель генетических различий между северной и южной популяциями составляет 0,089 $\pm 0,011$ и свидетельствует о существовании в оз. Байкал криптического комплекса, состоящего как минимум из двух видов байкалобделл. Дополнительный биоинформационный анализ с применением альтернативных алгоритмов (GMYC и ABGD) поддерживает гипотезу генетической дивергенции B. torquata на два вида.

Благодарности: Авторы признательны Н.В. Сороковиковой и М.А. Агееву за вклад в коллекцию пиявок. Работа выполнена при финансовой поддержке РФФИ (проекты № 17-29-05097 и № 20-3490043). 